\title{
Pioneer tree ferns influence community assembly in northern New Zealand forests
}

\author{
James M.R. Brock ${ }^{1 *}$, George L.W. Perry ${ }^{3}$, William G. Lee ${ }^{1,2}$, Luitgard Schwendenmann ${ }^{3}$ and \\ Bruce R. Burns ${ }^{1}$
}

${ }^{1}$ School of Biological Sciences, University of Auckland, Private Bag 92019, Auckland 1142, New Zealand

${ }^{2}$ Landcare Research, Private Bag 1930, Dunedin 9054, New Zealand

${ }^{3}$ School of Environment, University of Auckland, Private Bag 92019, Auckland 1072, New Zealand

*Author for correspondence (Email: jbro567@aucklanduni.ac.nz)

Published online: 12 October 2017

\begin{abstract}
Cyathea medullaris (Cyatheaceae) is a frequent pioneer of disturbed areas (e.g. landslides) or edge environments, sometimes forming near continuous canopies. We test the hypothesis that colonisation by this species as a pioneer alters the seedling assemblage to favour more shade-tolerant broadleaved trees than that beneath another common native pioneer (Kunzea robusta, Myrtaceae) in the same landscapes. We compared vegetation and abiotic characteristics of 166 sites across the Auckland region where C. medullaris or $K$. robusta were abundant $(\geq 20 \%$ basal area) along successional gradients. Using hierarchical classification and ordination, we identified distinct communities associated with the different pioneers. In the forests we consider, $C$. dealbata is another common understorey tree fern, which sometimes, but not always, co-occurs with $C$. medullaris. Cyathea medullaris / C. dealbata successions occurred on steep sites with lower annual water deficit whereas $K$. robusta / C. dealbata successions were located on flatter, drier sites. The prevalence of macro-charcoal in $K$. robusta / C. dealbata forest suggests the prominence of that community is in part an outcome of the increased importance of fire disturbance in New Zealand. Dominance of $C$. medullaris, with C. dealbata understoreys, influences community assembly of tree species towards dominance by shade-tolerant species, whereas seedlings of less shade-tolerant small-leaved species are more prevalent in K. robusta / C. dealbata forests. We provide evidence to suggest that, where present in early forest communities, high tree fern abundance influences the assembly of seedling communities, supporting our hypothesis. Contrary to previous suggestions, a high abundance or basal area of tree ferns on sites not historically affected by fire did not limit the establishment and growth of canopy trees including fleshy-fruited broadleaf species.
\end{abstract}

Keywords: biotic filter; Cyatheaceae; fire; multivariate analysis; succession; vegetation dynamics

\section{Introduction}

The distinctive traits of different pioneer species can influence community assembly and natural succession processes after disturbance (HilleRisLambers et al. 2012; Paterno et al. 2016). For example, the biotic influence of pioneers is evident in the different forest successions occurring beneath Kunzea spp. ${ }^{1}$ (Myrtaceae), a group of New Zealand native pioneers, compared with those beneath Ulex europaeus (Fabaceae), a non-native invasive nitrogen-fixing shrub in the same landscapes in New Zealand (Sullivan et al. 2007). However, abiotic filters (e.g. topography, soil conditions) initially underpin heterogeneous spatial patterns of pioneer taxa across the landscape, based on the tolerances of different pioneer species to disturbance type, abiotic characteristics and competition (Poff 1997; Ejrnæs et al. 2006; Perry et al. 2014). Community assembly will thus reflect historic disturbances, the abiotic conditions influencing pioneer establishment, and the subsequent biotic influence of the dominant pioneer (Connell \& Slatyer 1977; Weiher \& Keddy 1995; Sullivan et al. 2007; Burton et al. 2011).

The prevailing view of secondary successions initiated by fire and/or other stand destroying disturbances in New Zealand's temperate forest ecosystems is one where pioneer communities

\footnotetext{
${ }^{1}$ Following revision of Kunzea de Lange (2014), K. ericoides is likely to be at the Nelson sites and $K$. robusta around Wellington in the sites studied in Sullivan et al. (2007).
}

are commonly dominated by Myrtaceae, in particular Kunzea spp. $^{2}$ (de Lange 2014) and Leptospermum scoparium (Cameron 1960; Esler \& Astridge 1974; Wardle 1991; Smale et al. 1997; Richardson et al. 2014). These species arrived in New Zealand from Australia between 2-3 Ma, moving from a landscape where fire is a major determinant of plant traits and communities to New Zealand where natural fire pre-human was relatively infrequent (Thompson 1989; Battersby et al. 2017). However, since human arrival in New Zealand c. 1280 AD (Wilmshurst et al. 2008), fire frequency has dramatically increased in New Zealand's terrestrial ecosystems (Perry et al. 2012a), likely favouring Kunzea spp. and L. scoparium as pioneer species. The increased likelihood of occurrence of these Myrtaceae pioneers may influence the potential for other pioneers to establish (Esler 1967; Esler \& Astridge 1974; Smale 1994; Atkinson 2004; Perry et al. 2010).

\footnotetext{
${ }^{2}$ Previously recognised as Kunzea ericoides (A.Rich) Joy Thomps., Kunzea has recently been revised to recognise 10 species within New Zealand (de Lange 2014) with three commonly occurring in our study area: $K$. robusta, $K$. linearis and $K$. amathicola. The data used in this study, other than that which were collected by the authors, were obtained prior to this taxonomic revision and therefore all records refer to $K$. ericoides. Of the three species of Kunzea now present in the Auckland region, the most common forest associated species is K. robusta. Kunzea amathicola is strongly coastal and $K$. linearis is also restricted to coastal habitat around Auckland's Waitematā Harbour. Therefore, we assign all Kunzea records to $K$. robusta in the historic non-coastal forest plots compiled for this study.
} 
In Agathis australis (kauri) and conifer-broadleaved forest in the North Island, early successional communities dominated by tree ferns can often be a prominent feature of landscapes (Pope 1924; Silvester 1964; Beveridge 1973; Richardson et al. 2014; Fig. 1). Near-continuous canopies of pioneering Cyathea medullaris with dense understories including $C$. dealbata have been described (Pope 1924; Ritchie et al. 2003; Brock et al. 2016), but rarely studied. Early successional vegetation communities dominated by tree ferns are rare globally; however, Cyathea tree ferns acting as pioneers have been described in tropical ecosystems from Colombia (C. caracasana; Arens \& Sánchez Baracaldo 2000), Puerto Rico (C. bryophila and C. arborea; Shiels 2006; Weaver 2008; Walker et al. 2010), and on Trinidade Island off the coast of Brazil (C. copelandii; R. Alves \& N. Silva pers. comm.). Other early successional communities, developing on retired pasture and agricultural land or after fire, roadworks and landslides, may feature tree ferns as a prominent component, even if not as the dominant pioneers (Wardlaw 1931; Arens \& Sánchez Baracaldo 1998; Restrepo \& Vitousek 2001; Chacón-Labella et al. 2014). In New Zealand, succession through tree fern dominated stages has been described for Dicksonia squarrosa (Dicksoniaceae) and Cyathea smithii (Silvester 1964; Blaschke et al. 1992; Walker \& Sharpe 2010) where these establish approximately 25 years after the commencement of natural regeneration on landslides and in retired pastures; although none of these reported tree fern dominated stages are pioneering. We are unaware of any published studies of secondary succession involving tree fern pioneer dominated phases for any temperate forest ecosystem.

The two North Island pioneer species we focus on, $K$. robusta and $C$. medullaris, have many similar traits, including rapid height growth (c. $30 \mathrm{~cm} \mathrm{yr}^{-1}$ ), prolific production of wind-dispersed propagules, and relatively short life-spans (approx. 150 yrs; 120 years respectively) (Burrows 1973; Esler \& Astridge 1974; Esler 1976; Allen et al. 1992; Smale 1994; Brock et al 2016). Unlike New Zealand's other native tree ferns, $C$. medullaris will regenerate immediately after both gap-phase and landscape-level disturbances and is associated with high light environments (Wardle 1991; Large \& Braggins 2004). Cyathea medullaris is shade-intolerant (Bystriakova et al.2011) and often occupies habitats such as edges and canopy gaps (Pope 1924; Cockayne 1958; Large \& Braggins 2004). Kunzea robusta is similarly shade-intolerant and associated with open habitats (Burrows 1973; Wardle 1991).

In association with both of these pioneers, $C$. dealbata is a common component of the understory. However, in contrast to $C$. medullaris, $C$. dealbata is a relatively drought and shade-tolerant tree fern species (Bystriakova et al. 2011; Brock et al. 2016). Also, C. dealbata is a relatively long-lived, slow-growing tree fern, persisting in forests for up to 250 years (Wardle 1991; Bystriakova et al. 2011; Brock et al. 2016).

Tree ferns are likely to have an important influence on the regeneration niche of potentially dominant tree species in forests through macro-litterfall, shading, influences on nutrient cycling and provision of substrates for epiphytic woody seedlings (Gillman et al. 2004; Gaxiola et al. 2008; Brock et al. 2016). Tree ferns have been described as 'inhibiting' and 'slowing' forest succession (Connell \& Slatyer 1977; Walker et al. 2010). For example, Walker et al. (2010) describe the inhibitory influence of tree ferns on the establishment of woody forest canopy species in Puerto Rico, when compared to an area artificially cleared of tree ferns, over a 7 year period. On the other hand, Walker and Aplet (1994) suggest that, over the long-term, tree ferns act as a biotic filter on canopy species composition through their influence on nutrient cycling and soil moisture retention. In regenerating Agathis australis forest in New Zealand, Burns and Smale (1990) observed a lack of woody plant regeneration beneath $C$. dealbata (Cyatheaceae) and Norton (1991) recorded an absence of podocarp seedlings around tree ferns. More specifically, Richardson et al. (2014) suggested a causal link between high tree fern basal area (BA), concomitant with the browsing effect of invasive ungulates, and a significant reduction in the establishment success of fleshy-fruited canopy tree species in the Te Urewera area.

We hypothesise that $C$. medullaris will influence the communities developing beneath it in a way different to other

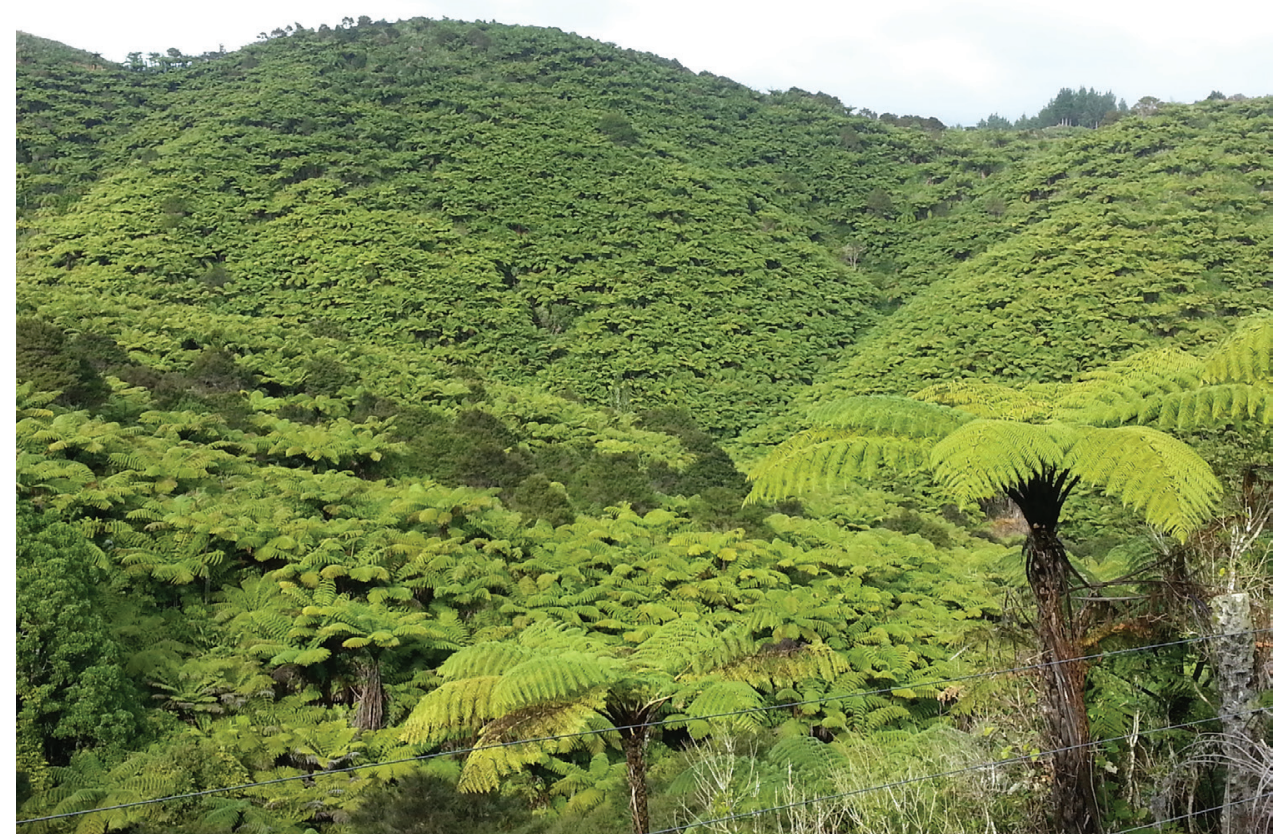

Figure 1. A near continuous canopy of C. medullaris across a slope on the north-eastern Hūnua Ranges. 
pioneer species such that they show distinct assemblages indicative of subsequent forest types. Furthermore, we hypothesise that these differences in species composition are not related to differences in geographic distance from seed sources, which is an alternative possible explanation for variation in early successional vegetation communities at landscape scales.

This study aims to identify whether: (1) successional communities dominated by either $C$. medullaris or $K$. robusta are associated with different abiotic conditions or disturbance types; (2) tree ferns influence community assembly and resultant forest composition; and (3) any differences in successional communities are determined by spatial separation of the plots in the landscape (i.e. dispersal failure) and not by abiotic conditions.

\section{Methods}

\section{Data collection}

\section{Vegetation community data}

To characterise early successional communities, we obtained a dataset from Auckland Council comprising $15420 \mathrm{~m} \times 20$ $\mathrm{m}$ permanent vegetation plots (data collected between 2009 and 2013; Fig. 2). These plots were a subset from a total of approximately 400 permanent plots established systematically across Auckland (Auckland Council 2014; Ruffell et al. 2015), with this subset targeting forest plots that support either $C$. medullaris and/or K. robusta with relative BAs of at least $20 \%$ of total BA. To improve representation of plots with a high abundance of $C$. medullaris, we supplemented the database with a further 12 plots across the Auckland region. These supplemental survey sites with dense tree fern canopies were identified using aerial photography accessed through the Auckland Council GIS map viewer (http://maps. aucklandcouncil.govt.nz/aucklandcouncilviewer). The survey methodology for the Auckland Council and supplemental plots followed permanent plot protocols established by Hurst and Allen (2007). Vegetation plots $(20 \mathrm{~m} \times 20 \mathrm{~m})$ were installed in areas of homogenous vegetation. For vascular plants, we recorded species and diameter at breast height of all trees (and tree ferns $)>2.5 \mathrm{~cm} \mathrm{DBH}$; counted saplings $(<2.5 \mathrm{~cm} \mathrm{DBH}$ but $>1.35 \mathrm{~m}$ tall) over the entire plot; and subsampled seedlings

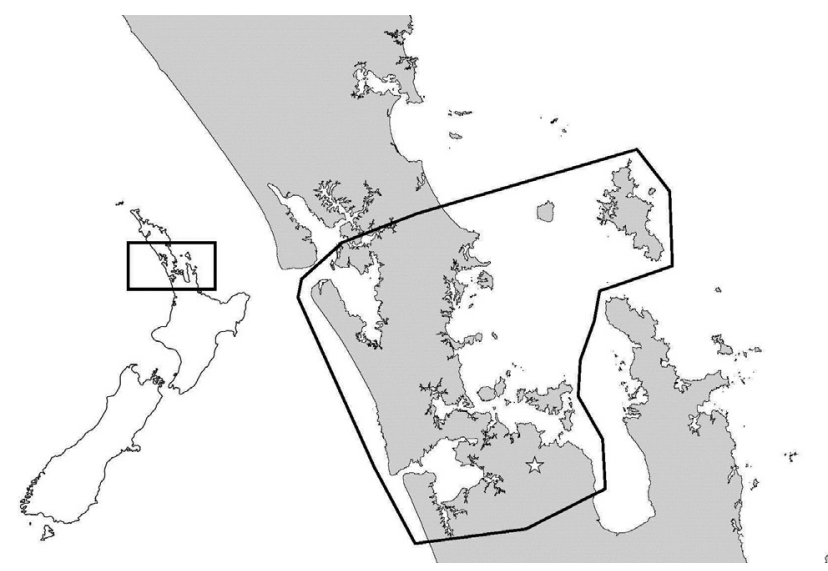

Figure 2. Survey sites were situated throughout the Auckland region, the extent of the sites is delineated by the black outline (latitudinal range of polygon: $36^{\circ} 02.85^{\prime} \mathrm{S}$ to $37^{\circ} 14.80^{\prime} \mathrm{S}$ ). Approximate location of Figure 1 indicated by star.
$(0-1.35 \mathrm{~m}$ tall $)$ in $240.49 \mathrm{~m}$ radius circular plots $\left(=0.75 \mathrm{~m}^{2}\right.$ area each) in the plot (Hurst \& Allen 2007). For each of the additional $C$. medullaris plots (12) and a comparable number of $K$. robusta plots (12) from the Auckland Council database, we collected data on a subset of biophysical conditions.

\section{Abiotic factors}

To obtain general abiotic data for each of the 166 plots, we downloaded spatial data comprising modelled abiotic values and geological data for the Auckland region from the LRIS portal (see https://lris.scinfo.org.nz and Table 1). We derived a topographic position index (TPI) layer from elevation data using the raster package (Hijmans 2015) in R version 3.2.3 ( $\mathrm{R}$ Core Team 2015). These data were loaded into a GIS programme (ArcMap ${ }^{\mathrm{TM}}$ 10.3.1) with the physical locations of the vegetation plots used to extract site specific values for these variables. Aspect data for each plot were converted from a bearing $\left(0-360^{\circ}\right)$ into partitioned values of 'northness' and 'eastness' (Zar 1999).

\section{Biophysical conditions}

We used sub-canopy photography using a hemispheric fisheye lens (Canon 450D, Sigma 4.5mm f/2.8 EX DC HSM) to quantify the understorey light environment in a subset of 24 plots, with photos taken at the northeast and southwest corners and the centre of the plot. Topography around the location of each photo was mapped using a compass and clinometer, and accounted for in the subsequent digital analysis. These photos were processed using Gap Light Analyzer 2.0 (Frazer et al. 1999) to estimate canopy openness as a proxy for understorey light environment.

Soil samples were collected from three random locations in each of the 24 plots using a coring ring of $10 \mathrm{~cm}$ diameter. Loose litter was removed, then a $5 \mathrm{~cm}$ deep sample was extracted from the organic soil layer. Soil samples were returned to the lab and dried at $35^{\circ} \mathrm{C}$ for 24 hours, root tissue removed, and the soil passed through a $2 \mathrm{~mm}$ sieve; samples for each plot were then combined. Samples were ground and analysed for total $\mathrm{C}$ and $\mathrm{N}$ concentration using an elemental analyser (TruSpec, LECO Corporation, St. Joseph, Michigan, USA). Soil standards (LECO Lot 1016, 1007) were used for calibration. Ten percent of samples were replicated and results were within the range of variation given for the standards. Analysis of $\mathrm{pH}$ was undertaken using the water method (\#106i). The remaining material was sent to the Landcare Research Environmental Chemistry Laboratory (Palmerston North) for analysis of available nitrogen (nitrate and ammonium by $2 \mathrm{M} \mathrm{KCl}$ extraction, method \#118) and phosphorus (Olsenavailable Phosphorus, method\#124), respectively (Blakemore et al. 1981). Descriptions of methods 106i, 118 and 124 are available from www.landcareresearch.co.nz/resources/ laboratories/environmental-chemistry-laboratory. A second 5 $\mathrm{cm}$ deep sample (using a cylindrical ring $10 \mathrm{~cm}$ in diameter) was taken at each location to derive bulk density; the samples were dried at $105^{\circ} \mathrm{C}$ for 24 hours and then weighed (Gradwell \& Birrell 1979)

Separate small samples (approx. $1 \mathrm{~cm}^{3}$ ) of soils from the organic soil layer were collected to estimate charcoal abundance as a proxy for recent fire history. These samples were prepared as described by Whitlock and Larsen (2001) and macro-charcoal fragments $(>2 \mathrm{~mm})$ counted under a dissecting microscope. 


\section{Analysis \\ Vegetation community data}

We analysed our data in four stages: (1) discrete vegetation assemblages were identified and their distinctiveness tested; (2) correlative relationships between these vegetation assemblages and environment were identified; (3) the potential influence of tree fern abundance on community assemblage was examined; and (4) the relative contributions of location and environment to variation in species composition were estimated.

\section{Identification of discrete vegetation assemblages}

For each plot, the BA of each species (combining trees and saplings) were calculated. The BA contribution of saplings (individuals $<2.5 \mathrm{~cm} \mathrm{DBH}$ ) was calculated using $1 \mathrm{~cm} \mathrm{DBH}$ as a standard for each sapling. We used BA values as an index of relative abundance of each of the species per plot to calculate dissimilarities among plots using the Bray-Curtis dissimilarity measure (Faith et al. 1987). This dissimilarity matrix was used to classify the plots using hierarchical agglomerative clustering with the complete linkage method (Quinn \& Keough 2002). Non-metric multidimensional scaling (nMDS) was used to ordinate and graphically represent the data (Clarke 1993; Quinn \& Keough 2002).

We used permutational multivariate analysis of variance (PERMANOVA;Anderson 2001) to assess whether the groups identified by hierarchical classification were compositionally distinct. As $K$. robusta is more prevalent in the landscape than C. medullaris, the number of plots representing these pioneers is potentially unequal. PERMANOVA is sensitive to the relative dispersion of groups in unbalanced designs (Anderson \& Walsh 2013); therefore, to assess whether any groups differed in their dispersion we used multivariate homogeneity of variance tests (PERMDISP2; Anderson 2006). To ensure the robustness of the analysis of any unbalanced groups, multiple permutations of PERMANOVA were undertaken using all plots $(n)$ from the smaller group against the same number of plots (n) randomly sampled, without replacement, from the larger group, as suggested by Alekseyenko (2016). Previously only weak relationships have been derived between tree fern BA and height / crown size (although allometric equations have been produced; Beets et al. 2012), casting doubt on the use of BA as an index of tree fern biomass. Therefore, multiple PERMANOVA analyses were undertaken on the groupings using density (species stems plot $^{-1}$ ) and presence/absence data, and finally with the $C$. medullaris and $K$. robusta species data values entirely removed. The latter analysis was designed to avoid potential circularity in our arguments, i.e. are the statistical assemblages produced by hierarchical classification defined by more than simply the presence of the dominant pioneer species? Non-metric multidimensional scaling(nMDS) was used to ordinate and graphically represent the data and the groupings produced by the presence/absence and density data. We used similarity percentage (SIMPER) analysis on the complete vegetation dataset to identify the species that contributed most to dissimilarities between groups. The groups were then named using the approach established by Atkinson (1985) based on the structural and compositional features characterising the vegetation communities in each group. To assess whether there was any consistency in the community composition of the groups, indicator value analysis for species combinations (De Cáceres et al. 2012) was applied to the forest stand and seedling data to identify any species that were faithful to the groups identified by the classification, irrespective of abundance.

\section{Abiotic factors}

Data were extracted from the GIS using the spatial analyst package to produce a matrix of abiotic and topographic conditions present at each of the 166 vegetation plots (Table 1). Collinear variables were identified using multiple pairwise correlations using a standard threshold of $r=|0.7|$, and removed from further analysis (Dormann et al. 2013). The data were standardised with a covariance matrix, and a principal components analysis (PCA) of the abiotic data then undertaken. Vectors representing the components explaining greater than $5 \%$ of variance were then fitted to the nMDS ordination of the floristic data; those components that had a statistically significant $(\mathrm{P}<0.05)$ association with the distribution of plots in ordination space were plotted.

\section{Regeneration niche}

An index of seedling height-abundances for each species per plot was derived by multiplying their density by their height

Table 1. LENZ modelled environmental variables used to analyse vegetation community data. All layers are at a spatial resolution of $25 \times 25 \mathrm{~m}$.

\begin{tabular}{|c|c|c|}
\hline Data layer & Units & $\begin{array}{l}\text { Range } \\
(5 \%-\text { median - 95\%) }\end{array}$ \\
\hline Acid soluble phosphorus & Index & $1-1-4$ \\
\hline Annual water deficit & $\mathrm{mm}$ & $0-38-119$ \\
\hline Exchangeable calcium & Index & $1-1-2$ \\
\hline Induration soil hardness & Index & $1-4-4$ \\
\hline Mean annual solar radiation & MJ.m ${ }^{-2} \cdot$ day $^{-1}$ & $149-152-155$ \\
\hline Mean annual temperature & ${ }^{\circ} \mathrm{C}$ & $11.3-14.4-15.8$ \\
\hline Mean minimum temperature of the coldest month & ${ }^{\circ} \mathrm{C}$ & $3.9-6.2-8.9$ \\
\hline Monthly water balance ratio & Index & $20-27-45$ \\
\hline October vapour pressure deficit & $\mathrm{kPa}$ & $25-36-41$ \\
\hline Slope & ${ }^{\circ}$ (degrees inclination) & $0-11-33$ \\
\hline Soil age & Index & $1-2-2$ \\
\hline Soil drainage & Index & $2-4-5$ \\
\hline Soil particle size & Index & $1-2-5$ \\
\hline Winter solar radiation & MJ.m ${ }^{-2} \cdot$ day $^{-1}$ & $5.8-6.0-6.5$ \\
\hline Fundamental soil layer (North Island) & Various & Various \\
\hline Topographic Position Index & Index & $71-471-34970$ \\
\hline
\end{tabular}


class (height class 1: $0-15 \mathrm{~cm} ; 2: 16-45 \mathrm{~cm} ; 3: 46-75 \mathrm{~cm} ; 4$ : 76-105 cm; 5: 106-135 cm; Hurst \& Allen 2007), then summing across the plot. Index values per species per plot were ordinated (nMDS with Bray-Curtis dissimilarity). PERMANOVA was used to assess separation in ordination space of plots on the basis of the previous groupings from the tree and sapling data. The abiotic data matrix had a new parameter 'tree fern BA' added, and another PCA and the analysis workflow described above repeated.

We used linear regressions between the total BA of tree ferns per plot and the numbers of woody species with BAs of $>0.5 \mathrm{~m}^{2} \mathrm{ha}^{-1}$ per plot to provide a comparison with the woody species richness vs. tree fern BA data presented by Richardson et al. (2014).

\section{Influence of space versus environment on composition}

Geographic (Euclidean) distances between all plots were calculated as was the Euclidean distances between sites based on the abiotic data matrix used in the PCA analysis. These abiotic and geographic dissimilarity matrices were, along with the original vegetation dissimilarity matrix, subjected to simple and partial permutational Mantel tests (Mantel \& Valand 1970).

All analyses were conducted using $\mathrm{R}$ version 3.2.3 ( $\mathrm{R}$ Core Team 2015) and the vegan 2.3-2 and indicspecies 1.7.5 libraries (De Cáceres et al. 2012; Oksanen et al. 2015).

\section{Results}

\section{Community analysis}

Hierarchical classification and ordination suggest that the 166 plots fell into two groups (Fig. 3). SIMPER analyses show that the dissimilarities between these two groups are based on the relative contributions of three species: $K$. robusta $(17.1 \%$ contribution) in one group, and the tree ferns, $C$. medullaris $(11.6 \%)$ and $C$. dealbata $(13.4 \%)$ in the other. Resampled PERMANOVA analyses showed that these groups were distinct in ordination space $\left(\mathrm{F}_{1,116}=27.06-35.86 ; \mathrm{P}<0.001\right)$, and PERMDISP2 analysis indicated that the two groups differ in their dispersion $\left(\mathrm{F}_{1,116}=0.04-5.95 ; \mathrm{P}<0.05\right)$, with the $C$. medullaris pioneer-associated group more compact than the $K$. robusta pioneer-associated group in ordination space. Analysis of the tree and sapling density data produced two groups largely consistent with the BA analysis: $93 \%$ of plots remained in the C. medullaris group, and $71 \%$ of the $K$. robusta plots remained in the same group. Multiple PERMANOVA analyses on these density data also showed that the distinction between the groups remained $\left(\mathrm{F}_{1,116}=16.60-24.14 ; \mathrm{P}<0.001\right)$. The hierarchical classification of the presence/absence data suggested three groups; $75 \%$ of the plots previously associated with the $C$. medullaris pioneer-associated communities remained distinct, while the $K$. robusta pioneer-associated plots were now represented by two groups. PERMANOVA
Vegetation units

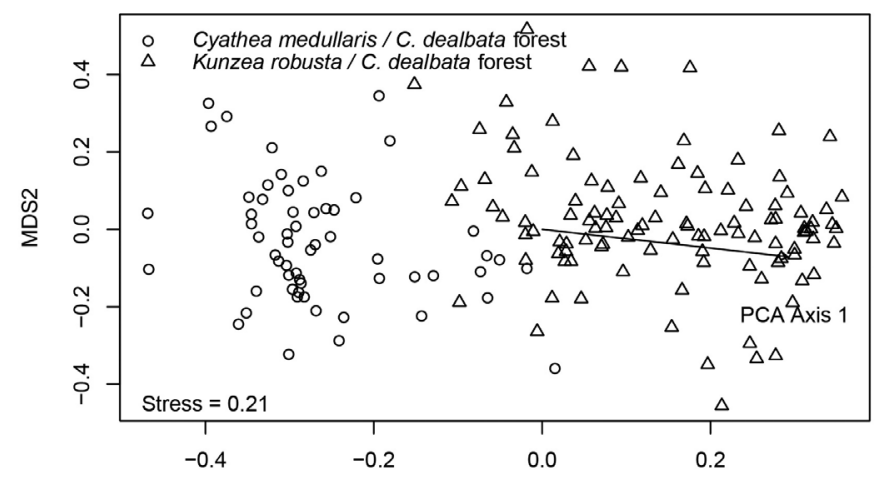

Cyathea dealbata

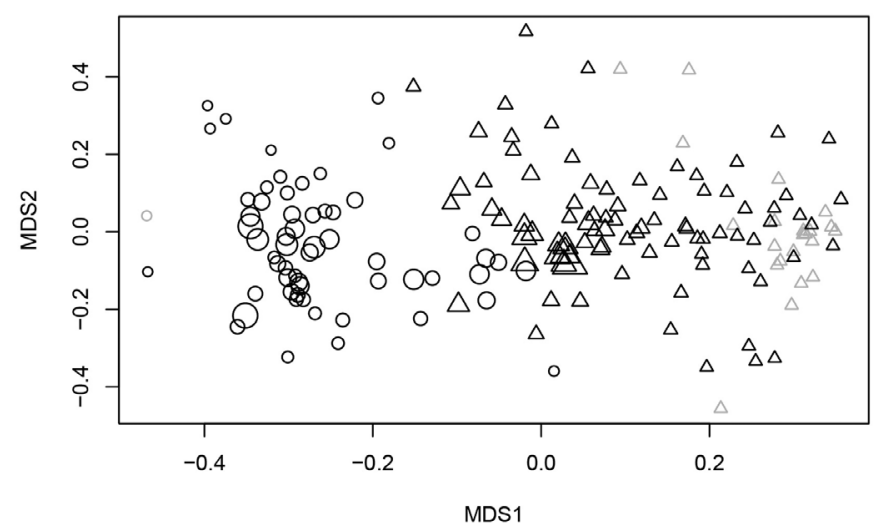

Cyathea medullaris

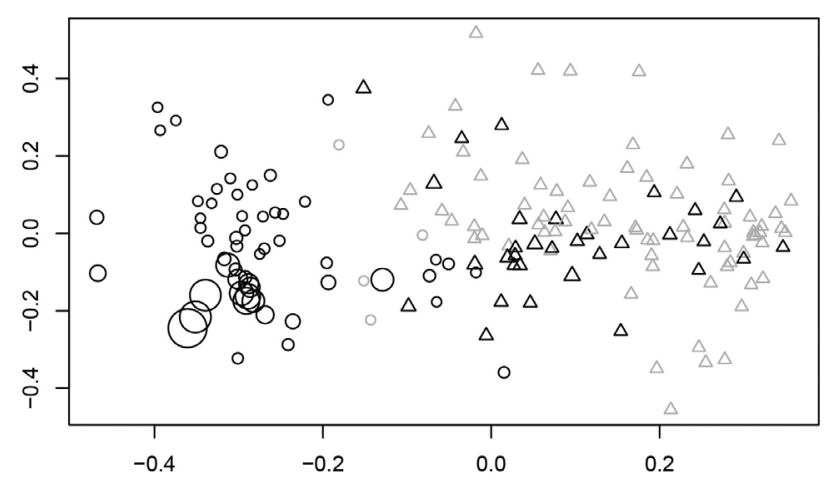

Kunzea robusta

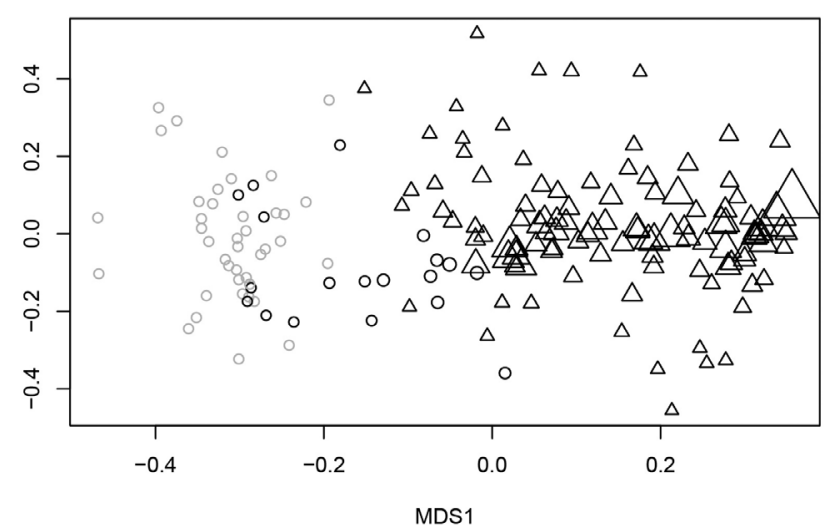

Figure 3. nMDS ordination of the vegetation data; stress for the ordination in two dimensions is 0.21 . The size of the symbols is proportional to the BA of $C$. medullaris, C. dealbata or $K$. robusta recorded in each plot. Grey symbols indicate plots where species were absent. The arrow indicates vector fits for the principal component factor associated with increasingly dry and flat sites that was significantly correlated $(\mathrm{P}=0.0001)$ with axis 1 of the nMDS. 
of the groupings of the presence/absence data confirmed that they were compositionally distinct $\left(\mathrm{F}_{1,116}=16.66-22.48\right.$; $\mathrm{P}<0.001)$. In the final tree and sapling vegetation analysis, in which the BA values of the pioneer species $C$. medullaris and $K$. robusta were removed, the $K$. robusta group fragmented further into six separate groups (ordinations of these datasets are in Appendix S1, see supplementary material). The communities were named, following Atkinson (1985), on the basis of their composition and structure as C. medullaris / C. dealbata forest, and $K$. robusta / C. dealbata forest. Cyathea dealbata was common to both groups; however, it had significantly greater basal area in the $C$. medullaris pioneer-associated communities $\left(13.4 \pm 9.2 \mathrm{~m}^{2} \mathrm{ha}^{-1}\right)$ than the $K$. robusta pioneer-associated communities $\left(4.9 \pm 7.5 \mathrm{~m}^{2} \mathrm{ha}^{-1}\right)$.

Indicator value analysis (using the complete BA dataset) recognised 14 species as 'faithful' (where $\mathrm{P} \leq 0.001$ after Bonferonni correction) to C. medullaris / C. dealbata forest and 10 species to $K$. robusta / C. dealbata forest (Table 2; Appendix S1). Shade-tolerant forest canopy species with large fleshy fruits such as Beilschmiedia tawa (Lauraceae) were faithful to $C$. medullaris / C. dealbata forest in the tree and sapling data, with broadleaved canopy species such as Hedycarya arborea (Monimiaceae) faithful in both tree, sapling and seedling data. Species such as Leucopogon fasciculatus (Ericaceae) and Phyllocladus trichomanoides (Podocarpaceae) were most commonly associated with $K$. robusta / C. dealbata forest (Table 2; see Appendix S2 in supplementary material).

\section{Abiotic factors}

The first PCA component was significantly correlated with Axis $1(\mathrm{P}<0.05)$ of the vegetation ordination, highlighted a gradient from steep $\left(13.4 \pm 6.5^{\circ}\right.$; mean $\left.\pm 1 \mathrm{SD}\right)$, moist (annual water deficit $=30.5 \pm 27.5 \mathrm{~mm}$ ) slopes towards lower elevation sites with increased annual water deficit $(53.2 \pm 25.9 \mathrm{~mm})$ and flatter topography $\left(10 \pm 5.6^{\circ}\right)$ (Fig. 3).

The organic soil layer showed significant differences in $\mathrm{pH}(C$. medullaris / C. dealbata forest $\bar{x}=5.83 \pm 0.25, K$. robusta $/ C$. dealbata forest $\bar{x}=4.96 \pm 0.26$ ) and ammonium concentrations (C. medullaris / C. dealbata forest $\bar{x}=130.65$ $\pm 80.38 \mathrm{mg} \mathrm{kg}^{-1}, K$. robusta / C. dealbata forest $\bar{x}=76.74 \pm$ $23.81 \mathrm{mg} \mathrm{kg}^{-1}$ ) between $C$. medullaris and K. robusta pioneerassociated communities, although the differing soil depths and densities at the sites meant little difference in ammonium pools (Table 3). The abundance of particulate macro-charcoal in the topsoil differed between the two communities (Table $3)$. Several $K$. robusta / C. dealbata forest sites had macrocharcoal amounts $\left(\bar{x}=185.82 \pm 221.86\right.$ pieces $\left.\mathrm{cm}^{-3}\right)$ indicative of recent, local fire(s), whereas there was little evidence for local fire events in the $C$. medullaris / C. dealbata forest sites $(\bar{x}=6.24 \pm 3.88)$.

\section{Regeneration niche}

The seedling communities of the $C$. medullaris / C. dealbata forest and $K$. robusta / $C$. dealbata forest were separated in ordination space (PERMANOVA: $\mathrm{F}_{1-116}=4.99-8.02 ; \mathrm{P}<$ 0.001; Fig. 4), consistent with the separation of the tree/sapling communities. Three factors had significant correlations $(\mathrm{P}<$ 0.05 ) with the ordination axes, and indicated that nMDS Axis 1 described a gradient of decreasing elevation, increasing temperature and annual water deficit $(\mathrm{P}=0.0001)$, and increasingly northerly-facing aspects on well-drained soils $(\mathrm{P}=0.0036)$. The gradient most associated with Axis 2 of the ordination was increasing tree fern BA $(62 \%$ of BA values represented by $C$. dealbata $)(\mathrm{P}=0.036)$.

Table 2. A summary of the canopy tree, understorey and tree fern species (tree, sapling and seedlings) that are identified as faithful to either $C$. medullaris / C. dealbata forest or $K$. robusta / C. dealbata forest; species presented here were faithful to a highly significant $(\mathrm{P}<0.001)$ degree. The complete list of faithful species is in Appendix S2.

Cyathea medullaris / Cyathea dealbata

Kunzea robusta / Cyathea dealbata

Tree and sapling data

\begin{tabular}{lll}
\hline Species & Family & Species \\
\hline Hedycarya arborea & Monimiaceae & Phyllocladus trichomanoides \\
Olearia rani & Asteraceae & Kunzea robusta Podocarpaceae \\
Beilschmiedia tawa & Lauraceae & Leucopogon fasciculatus \\
Dysoxylum spectabile & Meliaceae & Coprosma rhamnoides Ertaceae \\
Knightia excelsa & Proteaceae & Leptospermum scoparium \\
Melicytus ramiflorus & Violaceae & Olearia furfuracea \\
Rhopalostylis sapida & Arecaeceae & \\
Coprosma grandifolia & Rubiaceae & \\
Schefflera digitata & Araliaceae & \\
Brachyglottis repanda & Asteraceae & \\
Cyathea medullaris & Cyatheaceae & \\
Cyathea dealbata & Cyatheaceae & \\
Dicksonia squarrosa & Dicksoniaceae & \\
Cyathea smithii & Cyatheaceae & \\
\hline
\end{tabular}

\section{Seedling data}

Hedycarya arborea

Laurelia novae-zelandiae

Rhopalostylis sapida

Coprosma grandifolia

Schefflera digitata

\section{Monimiaceae}

Atherospermataceae

Arecaceae

Rubiaceae

Araliaceae
Phyllocladus trichomanoides

Coprosma arborea

Kunzea robusta

Coprosma rhamnoides

Leucopogon fasciculatus

Olearia furfuracea
Podocarpaceae

Rubiaceae

Myrtaceae

Rubiaceae

Ericaceae

Asteraceae 
Table 3. Ranges of biophysical conditions (5\% - median - 95\%) present in the organic soil layer in the C. medullaris / C. dealbata and K. robusta / C. dealbata forest communities (no multiple P-value corrections applied).

\begin{tabular}{|c|c|c|c|}
\hline Variable & Cyathea medullaris / Cyathea dealbata & Kunzea robusta / Cyathea dealbata & $\begin{array}{l}\text { ANOVA/ } \\
\text { Wilcoxon Test } p\end{array}$ \\
\hline \multicolumn{4}{|l|}{ Total Carbon } \\
\hline Conc. (\%) & $7.07-36.45-42.29$ & $3.34-9.68-21.62$ & $0.001 * *$ \\
\hline Pool (kg.m $\left.{ }^{-2}\right)$ & $0.39-4.97-9.09$ & $0.31-2.07-4.77$ & $0.022 *$ \\
\hline \multicolumn{4}{|l|}{ Total Nitrogen } \\
\hline Conc. (\%) & $0.15-0.24-0.51$ & $0.01-0.11-0.16$ & $0.007 * *$ \\
\hline Pool (kg.m $\left.{ }^{-2}\right)$ & $0.39-1.32-2.24$ & $0.22-0.49-1.00$ & $7.5 \times 10^{-4} * * *$ \\
\hline $\mathrm{C}: \mathrm{N}$ & $13.89-19.05-29.77$ & $11.27-20.39-37.82$ & $0.598 n s$ \\
\hline \multicolumn{4}{|l|}{ Nitrate $\mathrm{NO}_{3}$} \\
\hline Conc. (mg.kg $\left.{ }^{-1}\right)$ & $0.34-1.15-4.69$ & $0.45-2.33-59.29$ & $0.498 n s$ \\
\hline Pool $\left(\mathrm{g} \cdot \mathrm{m}^{-2}\right)$ & $0.00-0.02-0.07$ & $0.00-0.42-1.27$ & $0.264 n s$ \\
\hline \multicolumn{4}{|l|}{ Ammonium $\mathrm{NH}_{4}$} \\
\hline Conc. $\left(\mathrm{mg} \cdot \mathrm{kg}^{-1}\right)$ & $17.05-126.47-238.90$ & $43.83-74.42-113.67$ & $0.039 *$ \\
\hline $\operatorname{Pool}\left(\mathrm{g} \cdot \mathrm{m}^{-2}\right)$ & $0.33-1.54-4.56$ & $0.28-1.49-2.90$ & $0.458 n s$ \\
\hline $\mathrm{NH}_{4}: \mathrm{NO}_{3}$ & $30.14-111.02-203.66$ & $4.17-43.88-192.60$ & $0.917 n s$ \\
\hline \multicolumn{4}{|l|}{ Phosphorus } \\
\hline Conc. (mg.kg-1) & $6.13-20.21-36.20$ & $4.41-6.51-60.21$ & $0.130 n s$ \\
\hline Pool $\left(\mathrm{g} \cdot \mathrm{m}^{-2}\right)$ & $0.03-0.32-0.53$ & $0.03-0.14-1.74$ & $0.682 n s$ \\
\hline $\mathrm{pH}$ & $5.52-5.79-6.17$ & $4.57-5.01-5.27$ & $2 \times 10^{-8} * * *$ \\
\hline Charcoal (pieces) & $2.50-4.33-12.72$ & $37.01-58.42-589.27$ & $3 \times 10^{-5} * * *$ \\
\hline Canopy openness (\%) & $1.07-2.62-4.05$ & $1.58-3.79-11.67$ & $0.104 n s$ \\
\hline Litter depth $(\mathrm{cm})$ & $1.00-12.00-52.45$ & $0.00-3.50-14.18$ & $2 \times 10^{-16} * * *$ \\
\hline Soil depth $(\mathrm{cm})$ & $8.14-13.60-26.11$ & $1.30-4.20-10.39$ & $2 \times 10^{-16} * * *$ \\
\hline Tree fern BA $\left(\mathrm{m}^{2} \cdot \mathrm{ha}^{-1}\right)$ & $3.96-21.28-57.99$ & $0.00-2.14-22.39$ & $2.2 \times 10^{-16} * * *$ \\
\hline Bulk density g. $\mathrm{cm}^{-3}$ & $0.09-0.21-0.84$ & $0.34-0.47-0.82$ & $0.043 *$ \\
\hline
\end{tabular}



Figure 4. nMDS ordination of the heightweighted seedling abundance data; stress for the ordination plot is 0.25 . Arrows indicate vector fits for environmental variables with significant correlations $(\mathrm{P}<0.05)$; length of arrows indicates strength of correlation.
Woody species richness (only those with BAs $>0.5 \mathrm{~m}^{2}$ $\mathrm{ha}^{-1}$ counted) was not correlated with the total tree fern BA in either the entire vegetation dataset (slope $\pm \mathrm{SE}=0.05 \pm$ $0.03, \mathrm{P}=0.15$, adjusted $\mathrm{R}^{2}=0.01$; total tree fern $\mathrm{BA}$ range: $0.00-42.76, \bar{x}=5.54$ ), or in the C. medullaris / C. dealbata forest (slope $\pm \mathrm{SE}=-0.02 \pm 0.04, \mathrm{P}=0.59$, adjusted $\mathrm{R}^{2}=0.01$; total tree fern BA range: $0.00-38.94, \bar{x}=15.56$ ).

\section{Influence of spatial vs. abiotic effects on composition}

Analysis of the vegetation, abiotic and geographic dissimilarity matrices suggested a strong abiotic influence on the presence of C. medullaris / C. dealbata forest in the landscape (Table 4). There was no correlation between the abiotic variables and the distribution of K. robusta / C. dealbata forest in the landscape when these were considered independently of the $C$. medullaris /C. dealbata forest. Nor did we detect any dispersal limitation for successional species between the plots, with both simple and partial Mantel tests being non-significant.

\section{Discussion}

Our results identified two distinct pioneer vegetation communities in northern New Zealand forests; the switch that determines which trajectory is followed is initially determined on the basis of abiotic filters (Fig. 3). Pioneer establishment 
Table 4. Partial Mantel test values for all tree and sapling data across the Auckland region, and values for separate regeneration pathways under C. medullaris / C. dealbata forest and $K$. robusta / C. dealbata forest.

\begin{tabular}{lll} 
Vegetation communities (n) & Distance & Mantel $\boldsymbol{r}$ \\
\hline Combined pioneer communities $(\mathrm{n}=166)$ & Geographic: environmental partialled out & $-0.007 \mathrm{~ns}$ \\
& Environmental: geographic partialled out & $0.212^{* *}$ \\
$\begin{array}{l}\text { Cyathea medullaris / Cyathea dealbata forest } \\
(\mathrm{n}=59)\end{array}$ & Geographic: environmental partialled out & $-0.109 \mathrm{~ns}$ \\
$\begin{array}{l}\text { Kunzea robusta / Cyathea dealbata forest } \\
(\mathrm{n}=107)\end{array}$ & Environmental: geographic partialled out & $0.251^{* *}$ \\
& Geographic: environmental partialled out & $0.049 \mathrm{~ns}$ \\
& Environmental: geographic partialled out & $0.011 \mathrm{~ns}$
\end{tabular}

differentiates along a gradient dominated by changes in annual water deficit and slope. We identified a distinct pioneer community associated with the pioneer species C. medullaris, which promotes a seedling community modulated by the presence of $C$. medullaris and the presence of understorey $C$. dealbata, thus supporting our first hypothesis. This pathway is different to the successional trajectory associated with sites with $K$. robusta as a pioneer; even with $C$. dealbata present in the understorey of this forest type (though at lower abundance than the $C$. medullaris associated type). Seedling community composition was associated with tree fern BA and this suggests a response in the regeneration niche to the presence of abundant tree ferns. Although it is not possible to evince independent biotic and abiotic filters (Cadotte \& Tucker 2017), we suggest that, in line with the studies of Richardson et al. (2014), Coomes et al. (2005), Gillman et al. (2004) and Walker et al. (2010), tree ferns mediate the regeneration niche beneath them when in sufficient abundance.

In considering early successional communities, one of the key questions is how different compositions are influenced by the original local site conditions or by the dominant pioneer. The influence of dominant pioneer species on the availability of seedling sites may have long-term effects on the composition of vegetation communities (Sullivan et al. 2007; Burton et al. 2011; Paterno et al. 2016). We suggest that New Zealand pioneers, both native and exotic, do influence the regeneration niche of potential forest dominants, by layering a biotic filter on the original heterogeneity in the landscape (Grubb 1977; HilleRisLambers et al. 2012). Therefore, the relative abundance of these pioneers in the landscape is likely to influence the trajectory, timeline and climax vegetation of succession.

\section{Associations between $C$. medullaris and $K$. robusta pioneer} communities, abiotic conditions and disturbance types

The hierarchical classification of the forest community vegetation data indicated two distinct vegetation communities associated with the pioneers $C$. medullaris and $K$. robusta. These pioneer-associated communities arose from preferential establishment under different topographic and edaphic conditions, and after fire (as inferred from soil charcoal) in the case of $K$. robusta. Cyathea medullaris has several specific traits that facilitate the role of a pioneer species on vegetation-free disturbed soil, often associated with edge habitats and high light environments. In particular, it can establish on exposed bare soil surfaces (after landslides and anthropic activities that disturb soils e.g. forestry harvesting) in, what are for many tree ferns, high irradiance situations (Bystriakova et al. 2011). Cyathea medullaris pioneer-associated communities in the landscape (Fig. 1) lead to a (early) successional pathway supporting more notophyll (leaf length 75-125 mm) canopy species different from the well-described $K$. robusta succession
(Wardle 1991), which supports forest communities dominated by microphyll (leaf length $<75 \mathrm{~mm}$ ) taxa.

Kunzea robusta was more common as a pioneer species in drier, flatter, lower elevation areas (Burrows 1973); Burrell (1965) also observed an absence of Kunzea establishment on steep, wet slopes. In general, flat, relatively dry, lowland areas have been the focus of human activity over the last 750 years, particularly in terms of forest clearance of timber, intensive agriculture and susceptibility to anthropogenic fires (Ewers et al. 2006; Perry et al. 2012b). Fire destroys primary forest, maintains some fire-adapted successional communities, and causes soil and nutrient loss from ecosystems (Perry et al. 2012a). Evidence of significant volumes of macro-charcoal in the topsoil under $K$. robusta / $C$. dealbata forest suggests that this community establishes in areas of the contemporary landscape that have experienced recurrent twentieth century anthropogenic fires, particularly in steeper, wetter areas where we have identified conditions that might otherwise be suitable for the establishment of $C$. medullaris (Esler \& Astridge 1974). Anthropic fire has been frequently connected to the re-establishment of $K$. robusta in early successional communities (Payton et al. 1984; Perry et al. 2014). We suggest that the modern prevalence of $K$. robusta in the landscape, particularly as a pioneer species in regenerating forest, may, in part, represent reinvasion or encroachment in response to historic anthropogenic activities in the landscape, in particular fire and alteration of nutrient cycling (Perry et al. 2010). These K. robusta successions may develop where other naturally occurring successional systems would, in the absence of anthropic fire, have established.

Whilst it is almost impossible to disentangle the relative influence of fire and environment on the K. robusta / C. dealbata forest (Perry et al. 2010), the main abiotic drivers correlated with the establishment of the C. medullaris / $C$. dealbata forest were increased slope steepness, more neutral soil $\mathrm{pH}$, lower ambient temperatures and lower annual water deficit. A more level topography (for example lowland plains) in association with drier, more acidic soils, will likely facilitate the development of a K.robusta / C. dealbata forest, responding to soil catena from ridge to gully, and conditions most prone to fire and historic anthropogenic activities (logging, grazing etc.). The $C$. medullaris and K. robusta associated community establishment process is initiated by abiotic drivers and subsequently modulated and amplified in part by the traits of the pioneers, and the relative abundance of Cyathea tree ferns.

Influence of $C$. medullaris and $K$. robusta on the regeneration niche and compositional trajectory towards coniferbroadleaved forests vs. $A$. australis associated forests

Ordinations of the tree, sapling and seedling composition data suggest that pioneer communities are sorted on the basis of 
interactive macro-environmental gradients in temperature, elevation, topography and annual water deficit (Fig. 3). However, the BA of tree ferns, which appears decoupled from the abiotic drivers of pioneer species establishment, also influences the position of seedling communities in ordination space. Cyathea medullaris / C. dealbata forest supports the regeneration of broadleaved podocarp communities characterised by Laurelia novae-zelandiae (Atherospermataceae), B. tawa, Dysoxylum spectabile (Meliaceae) and Prumnopitys ferruginea (Podocarpaceae), whereas species regenerating in $K$. robusta / $C$. dealbata forest (relatively lower tree fern abundance) tend towards $A$. australis associated communities faithfully supporting species characteristic of drier, more acid and nutrient-poor soils such as Coprosma arborea (Rubiaceae) and P. trichomanoides (Burns \& Smale 1990; Wyse et al. 2013; Jager et al. 2015). However, this analysis does not suggest conifer-dominance in post- $K$. robusta / C. dealbata forest; the relatively small number of faithful species in this community compared to the Cyathea pioneer-associated system rather suggests a less predictable community composition in Kunzea pioneer-associated systems.

Studies describing patterns associated with tree fern prominence in forest understories suggest a suppression of podocarp regeneration (Wardle 1974; Smale et al. 1987; Coomes et al. 2005), and Norton (1991) suggests that seedling establishment is suppressed within tree fern drip-lines. Many of New Zealand's tall podocarp species are light demanding, hence shaded conditions are not conducive to regeneration (Ebbett \& Ogden 1998; Lusk et al. 2009). Our data indicate that complete suppression is not necessarily a trait of ecosystems with abundant tree ferns as a rich suite of species occur in such systems. Species associated with $C$. medullaris / C. dealbata forest such as D. spectabile and Beilschmiedia tawa are likely present in these communities as a result of their shade-tolerant life-history traits (Smale \& Kimberley 1983; Lusk et al. 2015). Furthermore, as seedlings, the shade tolerant $P$. ferruginea is a faithful component of the C. medullaris / C. dealbata forest suggesting that certain traits, in particular shade-tolerance, might be significant in determining community assembly and regeneration of the canopy in these systems. Prumnopitys ferruginea is also the most common species recorded in the seedling bank by Norton (1991) in a stand where tree ferns were an abundant component of the understorey.

No negative relationships were identified between total tree fern BA per plot and numbers of woody species in either the entire vegetation dataset, or the C. medullaris / C. dealbata forest in our study (Table 5); the BAs recorded ranged in excess $\left(>42.8 \mathrm{~m}^{2} \mathrm{ha}^{-1}\right)$ of those described in Richardson et al. (2014) $\left(21.2 \mathrm{~m}^{2} \mathrm{ha}^{-1}\right)$. We suggest that high tree fern BA per se does not suppress regenerating canopy species richness, and that other factors such as dispersal failure, herbivory and the long-term disturbance regime are a more significant driver for the recruitment failure and arrested successions observed by Richardson et al. (2014). The mechanisms underpinning the influence of tree ferns on seedling regeneration cannot be established from our data because they lack detailed spatial resolution and the location of the tree ferns in relation to the seedling subplots was not recorded; further experimental work is necessary to determine this relationship.

While nutrient concentrations in the organic layer of the two types of sites that were sampled were similar, they did differ in $\mathrm{pH}$, and total $\mathrm{C}$ and $\mathrm{N}$ pools; all three variables were higher in the organic layer sampled underneath tree fern dominated communities. Isolating the effect of tree ferns on soil nutrient status is difficult because tree ferns are patchily abundant in the understorey of $K$. robusta / C. dealbata forest. Moreover, tree fern impacts may be localised as indicated by Silvester (1964) for D. squarrosa. The distinct differences in $\mathrm{pH}$, total $\mathrm{N}$ and $\mathrm{C}$ across the two sets of communities may be a response to the presence of these distinct vegetation communities. Nevertheless, tree ferns will have a strong direct influence on the establishment of seedlings through a combination of lowering available light levels below the canopy and through macro-litterfall (Gillman et al. 2004) creating deep litter (Table 3 ).

Distinctive communities assembled under the canopies of C. medullaris and K. robusta were characterised by a recurring suite of high fidelity species that occurred in multiple tiers (for example, B. tawa, Beilschmiedia tarairi (Lauraceae), D. spectabile and Vitex lucens (Lamiaceae) were identified as faithful to the C. medullaris / C. dealbata forest). This outcome suggests that there is a consistent compositional assembly for the $C$. medullaris community. The $K$. robusta / C. dealbata forest, present in a narrower range of abiotic conditions than the $C$. medullaris / C. dealbata forest, was more variable in community composition, and had fewer faithful species as it fragmented into six separate groups with the removal of the pioneer species from the analysis. While it is difficult to quantify the extent of the contribution of tree fern presence, the number of species faithful to the $C$. medullaris / C. dealbata forest suggests that tree ferns function as a strong biotic filter. Teasing apart the influences of fire from the abiotic conditions of the K. robusta / C. dealbata forest limits interpretation, however, it is likely that the presence of $C$. dealbata in varying abundance within these systems affects the regeneration niche again through shading, nutrient cycling and macro-litterfall (Grubb 1977; Gillman et al. 2004; Perry et al. 2010; Richardson et al. 2014). The seedling community data available to this study were limited in the full consideration of tree ferns as drivers of community assembly; tree fern trunks provide establishment surfaces for many small-seeded species (Bellingham \& Richardson 2006; Gaxiola et al. 2008). Although the relatively

Table 5. Tree fern BAs and numbers of woody species with BAs $>0.5 \mathrm{~m}^{2} \mathrm{ha}^{-1}(\bar{x} \pm 1 . \mathrm{sd})$, in vegetation groups and in plots where tree fern BAs $>21.2 \mathrm{~m}^{2} \mathrm{ha}^{-1}$; significance values from pairwise t-test with Bonferroni correction.

Vegetation groups

${ }^{\mathrm{a}}$ Cyathea medullaris / Cyathea

dealbata forest $(\mathrm{n}=59)$

${ }^{\mathrm{b}}$ Kunzea robusta / Cyathea dealbata forest $(\mathrm{n}=107)$

${ }^{\mathrm{c} C o m m u n i t i e s ~ w h e r e ~ t r e e ~ f e r n ~}$

$\mathrm{BA}>21.2 \mathrm{~m}^{2} \mathrm{ha}^{-1}(\mathrm{n}=21)$

$\bar{x}$ no. woody species

$\begin{array}{lc}15.7 \pm 9.9^{\mathrm{b}, \mathrm{c} * * *} & 9.4 \pm 3.3 n s \\ 5.5 \pm 8.0^{\mathrm{a}, \mathrm{c} * * *} & 6.6 \pm 2.9^{\mathrm{a} * * *} \\ 28.7 \pm 5.9^{\mathrm{a}, \mathrm{b} * * *} & 7.8 \pm 2.9 \mathrm{~ns}\end{array}$

$\overline{\boldsymbol{x}}$ BA of tree fern 
smooth trunk surface of $C$. medullaris provides relatively few attachment points for higher plants (Beever 1984), the presence of $C$. dealbata is likely to influence assembly as an establishment surface.

\section{Influence of spatial versus abiotic effects on community composition}

The lack of a strong distance effect between plots vs. community dissimilarity (low values for Mantel tests of Euclidean distance) across the entire Auckland region (including the islands of the Hauraki Gulf) suggests local abiotic conditions are a stronger filter on community assembly in these ecosystems than is species dispersal. Furthermore, it would appear that the establishment of canopy tree species in regenerating forest is occurring despite seed predation and localised herbivory of seedlings and saplings (Smale et al. 1995; Grant-Hoffman et al. 2010; Morales et al. 2016). Where mammalian seed predators are present in the landscape, they preferentially use warmer, steeper topography, and prefer forest supporting Beilschmiedia spp., D. spectabile and $V$. lucens over K. robusta (King et al. 1996; Ogden \& Gilbert 2009). This pattern suggests that if seed predation were a significant determinant of differences between the seedling communities then the $C$. medullaris C. dealbata forest would be more affected, but this was not apparent in our analyses.

A common approach to the restoration of native forest systems in northern New Zealand is to plant $K$. robusta as a pioneer species. We suggest this study should encourage promoters of such regeneration and restoration schemes in the North Island to consider using C. medullaris where conditions are appropriate (increased slopes, more neutral soil $\mathrm{pH}$, lower ambient temperatures and lower annual water deficit). Planting, and establishment of tree fern sporophytes post-translocation, may not be successful, as sporophytes are not necessarily tolerant or easily transplanted (Eleutério \& Pérez-Salicrup 2009). Furthermore, little is known of the ecology of the gametophyte life-stage of the tree ferns limiting a 'self-seeding' approach by providing a source of spores. Herbicide spraying of Cenchrus clandestinum (kikuyu grass) at Tāwharanui Regional Park (north of Auckland) removed a dense, deep sward of grass from a steep bank on the southern slopes of the peninsula (on which the park is located) creating an opportunity for $C$. medullaris to establish (M. Maitland, pers. comm.). This outcome suggests that in some conditions it will be possible to induce a stand of $C$. medullaris to establish as a precursor to tall coastal broadleaved forest.

\section{Summary}

Forest regeneration following stand-level vegetation removal in northern New Zealand can commence with pioneer communities of either $K$. robusta or C. medullaris. Tree ferns as pioneers are rare globally, particularly in the temperate biome, and in this study we show that they favour steep slopes, with decreased annual water deficit. Under these conditions shade-tolerant broadleaved and podocarp forest species establish beneath the tree ferns. In contrast, $K$. robusta is more common on flat, dry sites that have often experienced fire, and is associated with less shade-tolerant sclerophyllous small-leaved forest species. The communities that establish with these distinct pioneers are different, although both comprise a $C$. dealbata understorey, and appear to support distinct vegetation associations: $C$. medullaris systems are associated with a broadleaved-podocarp forest community; $K$. robusta systems are associated with $A$. australis communities.

The presence of a high abundance or biomass of $C$. medullaris and $C$. dealbata on sites not historically affected by fire did not limit the establishment of shade-tolerant canopy trees. Furthermore, the presence of tree ferns was strongly associated with seedling communities in ordination space, which suggests biotic filtering across all communities where tree ferns are recorded, both as pioneers, and in the understorey. We found no evidence of community composition being limited by a lack of seed dispersal agents, nor evidence to suggest that high tree fern density is a limiting factor on succession.

This description of a pioneer community dominated by tree ferns is novel for the southern temperate region. Although it is not possible to clarify landscape-level feedbacks from correlative studies alone, this study serves to demonstrate the likely significant influence of tree ferns in the early development of forest ecosystems. Future studies attempting to disentangle the role of tree ferns as determinants of community assembly should focus along gradients of dominance of $K$. robusta vs. $C$. dealbata. In contrast to $K$. robusta vs. $C$. medullaris, the abiotic controls on these species' establishment are less dichotomous, and hence the influence of tree fern presence on community assembly more detectable. Applied research into how to 'seed' $C$. medullaris into the landscape, coupled with research into the ecology of the gametophyte of this unusual tree fern species would usefully inform future habitat restoration projects.

\section{Acknowledgements}

We wish to thank the Manuhiri Kaitiaki Charitable Trust, private landowners and Auckland Council for access to field sites, as well as all the many volunteers who helped in the field. We also thank Auckland Council for allowing access to an extensive database on permanent plots in the Auckland region. Peter Bellingham and an anonymous reviewer provided constructive criticisms that helped to improve this manuscript. This work was part-funded by the Centre for Biodiversity and Biosecurity (University of Auckland and Landcare Research).

\section{References}

Alekseyenko AV 2016. Multivariate Welch t-test on distances. Bioinformatics 32: 3552-3558.

Allen RB, Partridge TR, Efford M 1992. Ecology of Kunzea ericoides (A Rich) J Thompson (kanuka) in east Otago, New Zealand. New Zealand Journal of Botany 30: 135-149.

Anderson MJ 2001. A new method for non-parametric multivariate analysis of variance. Austral Ecology 26: 32-46.

Anderson MJ 2006. Distance-based tests for homogeneity of multivariate dispersions. Biometrics 62: 245-253.

Anderson MJ, Walsh DCI 2013.PERMANOVA,ANOSIM, and the Mantel test in the face of heterogeneous dispersions: what null hypothesis are you testing? Ecological Monographs 83: 557-574.

Arens NC, Sánchez Baracaldo P 1998. Distribution of tree ferns (Cyatheaceae) across the successional mosaic in an Andean cloud forest, Nariño, Colombia. American Fern Journal 88: 60-71. 
Arens NC, Sánchez Baracaldo P 2000. Variation in tree fern stipe length with canopy height: tracking preferred habitat through morphological change. American Fern Journal 90: $1-15$.

Atkinson IAE 1985. Derivation of vegetation mapping units for an ecological survey of Tongariro National Park, North Island, New Zealand. New Zealand Journal of Botany 23: $361-378$.

Atkinson IAE 2004. Successional processes induced by fires on the northern offshore islands of New Zealand. New Zealand Journal of Ecology 28: 181-193.

Auckland Council 2014. Environmental monitoring plan 2014. Research, Investigations and Monitoring Unit. Auckland, Auckland Council. 53 p.

Battersby PF, Wilmshurst JM, Curran TJ, McGlone MS, Perry GLW 2017. Exploring fire adaptation in a land with little fire: serotiny in Leptospermum scoparium (Myrtaceae). Journal of Biogeography 44: 1306-1318.

Beets PN, Kimberley MO, Oliver GR, Pearce SH, Graham JD, Brandon A 2012. Allometric equations for estimating carbon stocks in natural forest in New Zealand. Forests 3: 818-839.

Beever JE 1984. Moss epiphytes of tree-ferns in a warmtemperate forest, New Zealand. Journal of the Hattori Botanical Society 56: 89-95.

Bellingham PJ, Richardson SJ 2006. Tree seedling growth and survival over 6 years across different microsites in a temperate rain forest. Canadian Journal of Forest Research 36: 910-918.

Beveridge AE 1973. Regeneration of podocarps in a central North Island forest. New Zealand Journal of Forestry 18: 23-35.

Blakemore LC, Searle PL, Daly BK 1981. Methods for chemical analysis of soils. New Zealand Soil Bureau Scientific Report 10A. Wellington, New Zealand, Department of Scientific and Industrial Research. 102 p.

Blaschke PM, Trustrum NA, DeRose RC 1992. Ecosystem processes and sustainable land use in New Zealand steeplands. Agriculture, Ecosystems and Environment 41: 153-178.

Brock JMR, Perry GLW, Lee WG, Burns BR 2016. Tree fern ecology in New Zealand: a model for southern temperate rainforests. ForestEcology and Management 375: 112-126.

Burns BR, Smale MC 1990. Changes in structure and composition overfifteen years in a secondary kauri(Agathis australis)-tanekaha(Phyllocladus trichomanoides) forest stand, Coromandel Peninsula, New Zealand. New Zealand Journal of Botany 28: 141-158.

Burrell J 1965. Ecology of Leptospermum in Otago. New Zealand Journal of Botany 3: 3-16.

Burrows CJ 1973. The ecological niches of Leptospermum scoparium and L. ericoides (Angiospermae: Myrtaceae). Mauri Ora 1: 5-12.

Burton JI, Mladenoff DJ, Clayton MK, Forrester JA 2011. The roles of environmental filtering and colonization in the fine-scale spatial patterning of ground-layer plant communities in north temperate deciduous forests. Journal of Ecology 99: 764-776.

Bystriakova N, Bader M, Coomes DA 2011. Long-term tree fern dynamics linked to disturbance and shade tolerance. Journal of Vegetation Science 22: 72-84.

Cadotte MW, Tucker CM 2017. Should environmental filtering be abandoned? Trends in Ecology \& Evolution 32: 429-437.
Cameron RJ 1960. Natural regeneration of podocarps in the forests of the Whirinaki River Valley. New Zealand Journal of Forestry 8: 337-354.

Chacón-Labella J, De la Cruz M, Vicuña R, Tapia K, Escudero A 2014. Negative density dependence and environmental heterogeneity effects on tree ferns across succession in a tropical montane forest. Perspectives in Plant Ecology, Evolution and Systematics 16: 52-63.

Clarke KR 1993. Non-parametric multivariate analyses of changes in community structure. Australian Journal of Ecology 18: 117-143.

Cockayne L 1958. The vegetation of New Zealand. Weinheim, Germany, H. R. Engelmann (J. Cramer). 576 p.

Connell JH, Slatyer RO 1977. Mechanisms of succession in natural communities and their role in community stability and organization. The American Naturalist 111: 1119-1144.

Coomes DA, Allen RB, Bentley WA, Burrows LE, Canham CD, Fagan L, Forsyth DM, Gaxiola-Alcantar A, Parfitt RL, Ruscoe WA, Wardle DA, Wilson DJ, Wright EF 2005. The hare, the tortoise and the crocodile: the ecology of angiosperm dominance, conifer persistence and fern filtering. Journal of Ecology 93: 918-935.

De Cáceres M, Legendre P, Wiser SK, Brotons L 2012. Using species combinations in indicator value analyses. Methods in Ecology and Evolution 3: 973-982.

de Lange PJ 2014. A revision of the New Zealand Kunzea ericoides (Myrtaceae) complex. PhytoKeys 2014: 1-185.

Dormann CF, Elith J, Bacher S, Buchmann C, Carl G, Carré G, Marquéz JRG, Gruber B, Lafourcade B, Leitão PJ, Münkemüller T, McClean C, Osborne PE, Reineking B, Schröder B, Skidmore AK, Zurell D, Lautenbach S 2013. Collinearity: a review of methods to deal with it and a simulation study evaluating their performance. Ecography 36: $27-46$

Ebbett RL, Ogden J 1998. Comparative seedling growth of five endemic New Zealand podocarp species under different light regimes. New Zealand Journal of Botany 36: 189-201.

Ejrnæs R, Bruun HH, Graae BJ 2006. Community assembly in experimental grasslands: suitable environment or timely arrival? Ecology 87: 1225-1233.

Eleutério AA, Pérez-Salicrup D 2009. Transplanting tree ferns to promote their conservation in Mexico. American Fern Journal 99: 279-291.

Esler AE 1967. The vegetation of Kapiti Island. New Zealand Journal of Botany 5: 353-393.

Esler AE 1976. Succession of fronds of mamaku (Cyathea medullaris). Wellington Botanical Society Bulletin 39: 41-43.

Esler AE, Astridge SJ 1974. Tea tree (Leptospermum) communities of the Waitakere Ranges, Auckland, New Zealand. New Zealand Journal of Botany 12: 485-501.

Ewers RM, Kliskey AD, Walker S, Rutledge D, Harding JS, Didham RK 2006. Past and future trajectories of forest loss in New Zealand. Biological Conservation 133: 312-325.

Faith DP, Minchin PR, Belbin L 1987. Compositional dissimilarity as a robust measure of ecological distance. Vegetatio 69: 57-68.

Frazer GW, Canham CD, Lertzman KP 1999. Gap Light Analyzer pp Imaging software to extract canopy structure and gap light transmission indices from true-colour fisheye photographs, users manual and program documentation. Simon Fraser University, Burnaby, Vancouver, British Colombia, Canada. 
Gaxiola A, Burrows LE, Coomes DA 2008. Tree fern trunks facilitate seedling regeneration in a productive lowland temperate rain forest. Oecologia 155: 325-335.

Gillman LN, Ogden J, Wright SD, Stewart KL, Walsh DP 2004. The influence of macro-litterfall and forest structure on litterfall damage to seedlings. Austral Ecology 29: 305-312.

Gradwell MW, Birrell KS 1979. Methods for physical analysis of soils. New Zealand Soil Bureau Scientific Report 10C. Wellington, New Zealand, Department of Scientific and Industrial Research. 66 p.

Grant-Hoffman MN, Mulder CPH, Bellingham PJ 2010 Effects of invasive rats and burrowing seabirds on seeds and seedlings on New Zealand islands. Oecologia 162: 1005-1016.

Grubb PJ 1977. The maintenance of species-richness in plant communities: the importance of the regeneration niche. Biological Reviews 52: 107-145.

Hijmans RJ 2015. raster: geographic data analysis and modeling. $\mathrm{R}$ package version 2.5-2. https://CRAN.Rproject.org/package=raster.

HilleRisLambers J, Adler PB, Harpole WS, Levine JM, Mayfield MM 2012. Rethinking community assembly through the lens of coexistence theory. Annual Review of Ecology, Evolution, and Systematics 43: 227-248.

Hurst JM, Allen RB 2007. The Recce method for describing New Zealand vegetation: field protocols. Lincoln, New Zealand, Manaaki Whenua Landcare Research. 41 p.

Jager MM, Richardson SJ, Bellingham PJ, Clearwater MJ, Laughlin DC 2015. Soil fertility induces coordinated responses of multiple independent functional traits. Journal of Ecology 103: 374-385.

King CM, Innes JG, Flux M, Kimberley MO, Leathwick JR, Williams DS 1996. Distribution and abundance of small mammals in relation to habitat in Pureora Forest Park. New Zealand Journal of Ecology 20: 215-240.

Large MF, Braggins JE 2004. Tree ferns. Cambridge, Timber Press. $359 \mathrm{p}$.

Lusk CH, Duncan RP, Bellingham PJ 2009. Light environments occupied by conifer and angiosperm seedlings in a New Zealand podocarp - broadleaved forest. New Zealand Journal of Ecology 33: 83-89.

Lusk C, Jorgensen MA, Bellingham PJ 2015. A coniferangiosperm divergence in the growth vs. shade tolernace trade-off underlies the dynamics of a New Zealand warmtemperate rain forest. Journal of Ecology 103: 479-488.

Mantel N, Valand RS 1970. A technique of nonparametric multivariate analysis. Biometrics 26: 547-558.

Morales NS, Perry GLW, Burns BR 2016. Fencing is not enough to reinstate regeneration: evidence from a large fruited canopy tree Beilschmiedia tawa. Forest Ecology and Management 376: 36-44.

Norton DA 1991. Seedling and sapling distribution patterns in a coastal podocarp forest, Hokitika Ecological District, New Zealand. New Zealand Journal of Botany 29: 463-466.

Ogden J, Gilbert J 2009. Prospects for the eradication of rats from a large inhabited island: community based ecosystem studies on Great Barrier Island, New Zealand. Biological Invasions 11: 1705-1717.

Oksanen J, Blanchet FG, Kindt R, Legendre P, Minchin PR, O'Hara RB, Simpson GL, Solymos P, Stevens MHH, Wagner H 2015. vegan: community ecology package. R package version 2.3-2.

Paterno GB, Siqueira Filho JA, Ganade G 2016. Species- specific facilitation, ontogenetic shifts and consequences for plant community succession. Journal of Vegetation Science 27: 606-615.

Payton IJ,Allen RB, Knowlton JE 1984. A post-fire succession in the northern Urewera forests North Island, New Zealand. New Zealand Journal of Botany 22: 207-222.

Perry GLW, Ogden J, Enright NJ, Davy LV 2010. Vegetation patterns and trajectories in disturbed landscapes, Great Barrier Island, northern New Zealand. New Zealand Journal of Ecology 34: 311-323.

Perry GLW, Wilmshurst JM, McGlone MS, McWethy DB, Whitlock C 2012a. Explaining fire-driven landscape transformation during the initial burning period of New Zealand's prehistory. Global Change Biology 18: 1609-1621.

Perry GLW, Wilmshurst JM, McGlone MS, Napier A 2012b. Reconstructing spatial vulnerability to forest loss by fire in pre-historic New Zealand. Global Ecology and Biogeography 21: 1029-1041.

Perry GLW, Wilmshurst JM, McGlone MS 2014. Ecology and long-term history of fire in New Zealand. New Zealand Journal of Ecology 38: 157-176.

Poff NL 1997. Landscape filters and species traits: towards mechanistic understanding and prediction in stream ecology. Journal of the North American Benthological Society 16: 391-409.

Pope A 1924. The role of the tree-fern in the New Zealand bush. New Zealand Journal of Science and Technology 7: $52-61$.

Quinn GP, Keough MR 2002. Experimental design and data analysis for biologists. Cambridge, UK, Cambridge Unversity Press. 539 p.

R Core Team 2015. R: a language and environment for statistical computing. R Foundation for Statistical Computing, Vienna, Austria.

Restrepo C, Vitousek P 2001. Landslides, alien species, and the diversity of a Hawaiian montane mesic ecosystem. Biotropica 33: 409-420.

Richardson SJ, Holdaway RJ, Carswell FE 2014. Evidence for arrested successional processes after fire in the Waikare River catchment, Te Urewera. New Zealand Journal of Ecology 38: 221-229.

Ritchie J, Easton L, Lambert R 2003. Waikumete cemetery and reserve conservation management plan. Auckland, New Zealand, Waitakere City Council-Te Taiao o Waitakere. $169 \mathrm{p}$.

Ruffell J, Innes J, Bishop C, Landers T, Khin J, Didham RK 2015. Using pest monitoring data to inform the location and intensity of invasive-species control in New Zealand. Biological Conservation 191: 640-649.

Shiels AB 2006. Leaf litter decomposition and substrate chemistry of early successional species on landslides in Puerto Rico. Biotropica 38: 348-353.

Silvester WB 1964. Forest regeneration problems in the Hunua Ranges, Auckland. Proceedings of the New Zealand Ecological Society 11: 1-5.

Smale MC 1994. Structure and dynamics of kanuka (Kunzea ericoides var. ericoides) heaths on sand dunes in Bay of Plenty, New Zealand. New Zealand Journal of Botany 32: 441-452.

Smale MC, Kimberley M 1983. Regeneration patterns in Beilschmiedia tawa-dominant forest at Rotoehu. New Zealand Journal of Forestry Science 13: 58-71.

Smale MC, Beveridge AE, Pardy GF, Steward GA 1987. 
Selective logging in podocarp/tawa forest at Pureora and Whirinaki. New Zealand Journal of Forestry Science 17: 29-50.

Smale MC, Hall GMJ, Gardner RO 1995. Dynamics of kanuka (Kunzea ericoides) forest on South Kaipara spit, New Zealand, and the impact of fallow deer (Dama dama). New Zealand Journal of Ecology 19: 131-141.

Smale MC, McLeod M, Smale PN 1997. Vegetation and soil recovery on shallow landslide scars in tertiary hill country, East Cape region, New Zealand. New Zealand Journal of Ecology 21: 31-41.

Sullivan JJ, Williams PA, Timmins SM2007. Secondary forest succession differs through naturalised gorse and native kānuka near Wellington and Nelson. New Zealand Journal of Ecology 31: 22-38.

Thompson J 1989. A revision of the genus Leptospermum (Myrtaceae). Telopea 3: 301-449.

Walker J, Sharpe JM 2010. Ferns, disturbance and succession. In: Mehltreter K, Walker J, Sharpe JM eds. Fern ecology. Cambridge, Cambridge University Press. Pp. 177-219.

Walker LR, Aplet GH 1994. Growth and fertilization responses of Hawaiian tree ferns. Biotropica 26: 378-383.

Walker LR, Landau FH, Velázquez E, Shiels AB, Sparrow AD 2010. Early successional woody plants facilitate and ferns inhibit forest development on Puerto Rican landslides. Journal of Ecology 98: 625-635.

Received 7 April 2017; accepted 14 August 2017

Editorial board member: Peter Bellingham; Acting Scientific Editor: Jo Monks

\section{Supplementary Material}

Additional supporting information may be found in the online version of this article:

Appendix S1. Ordinations of vegetation data using (i) frequency data (S1.1); (ii) presence / absence data (in place of BA data; S1.2); and (iii) BA data with values for Cyathea medullaris and Kunzea robusta removed (S1.3).

Appendix S2. Table of complete output from indicator species analysis.

The New Zealand Journal of Ecology provides online supporting information supplied by the authors where this may assist readers. Such materials are peer-reviewed and copy-edited but any issues relating to this information (other than missing files) should be addressed to the authors.
Wardlaw CW 1931. Observations on the dominance of pteridophytes on some St Lucia soils. Journal of Ecology 19: 60-63.

Wardle P 1974. The kahikatea (Dacrycarpus dacrydioides) forest of South Westland. Proceedings of the New Zealand Ecological Society 21: 62-71.

Wardle P 1991. Vegetation of New Zealand. Cambridge, UK, Cambridge University Press. 672 p.

Weaver PL 2008. Dwarf forest recovery after disturbances in the Luquillo Mountains of Puerto Rico. Caribbean Journal of Science 44: 150-163.

Weiher E, Keddy PA 1995. The assembly of experimental wetland plant communities. Oikos 73: 323-335.

Whitlock C, Larsen C 2001. Charcoal as a fire proxy. In: Smol JP, Birks HJB, Last WM, Bradley RS, Alverson K eds. Tracking environmental change using lake sediments: terrestrial, algal, and siliceous indicators. Dordrecht, Springer Netherlands. Pp. 75-97.

Wilmshurst JM, Anderson AJ, Higham TFG, Worthy TH 2008. Dating the late prehistoric dispersal of Polynesians to New Zealand using the commensal Pacific rat. Proceedings of the National Academy of Sciences of the United States of America 105: 7676-7680.

Wyse SV, Burns BR, Wright SD 2013. Distinctive vegetation communities are associated with the long-lived conifer Agathis australis (New Zealand kauri, Araucariaceae) in New Zealand rainforests. Austral Ecology 39: 388-400.

Zar JH 1999. Biostatistical Aanalysis. New Jersey, Prentice Hall. 944 p. 